\title{
Synthesis of cationic gold(III) complexes using iodine(III)
}

\author{
Mohammad Albayer and Jason L. Dutton*
}

Department of Chemistry and Physics, La Trobe Institute for Molecular Science, La Trobe University, Melbourne, Victoria, Australia, 3086.

Corresponding author. Email: j.dutton@latrobe.edu.au.

\begin{abstract}
We report the synthesis and characterization of cationic $\mathrm{Au}(\mathrm{III})$ complexes supported by nitrogen-based ligands. The synthesis is achieved by reacting $\mathrm{Au}(\mathrm{I})$ complexes $[\mathrm{Au}(\mathrm{N}-$ Me-imidazole $\left.)_{2}\right]^{+}$and $[\mathrm{Au}(\text { pyridine })(\mathrm{NHC})]^{+}$with iodine(III) reagents yielding a series of cationic gold(III) complexes. In contrast, reactions of phosphine ligated gold(I) complexes with iodine(III) reagents resulted in the oxidation of the phosphine ligand.
\end{abstract}




\section{Introduction}

Gold I/III redox catalysis has attracted much attention recently in organic synthesis, ${ }^{1}$ however, oxidative addition reactions are not readily accessible at $A u(I)$ due to the high oxidation potential of $\mathrm{Au}(\mathrm{I}) .{ }^{2}$ For catalysis to occur via $\mathrm{Au}(\mathrm{I}) / \mathrm{Au}(\mathrm{III})$ redox forcing conditions are required which can be achieved using external oxidants such as trivalent iodine reagents. ${ }^{3-9}$ In one report, Blank and de Frémont have displayed the use of $\mathrm{PhICl}_{2}$ in generating (NHC)-Au(III) complexes. However, attempts in generating tricationic $\mathrm{Au}(\mathrm{III})$ complexes bound by only neutral ligands by exchanging the chlorides with pyridines using silver salts were unsuccessful (Scheme 1). ${ }^{10}$

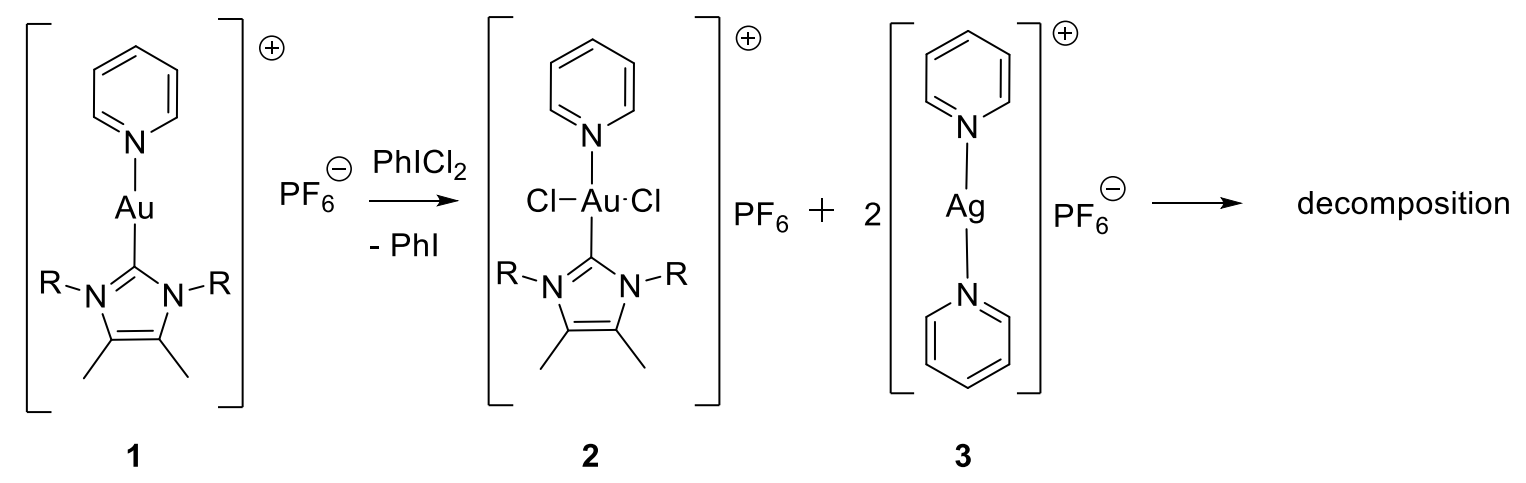

Scheme 1. Attempts to generate tricationic $\mathrm{Au}(\mathrm{III})$ complexes.

Our group has demonstrated the use of I(III) based reagents in accessing tricationic $\mathrm{Au}$ (III) complexes. These reagents have proved to be an effective oxidant for the synthesis of homoleptic and pseudo-homoleptic tricationic Au(III) complexes (Scheme 2 ). In the reaction of $\mathbf{4}$ with $\mathbf{5 R}$, compounds of the class $\mathbf{6 R}$ were generated in high yields. In contrast, the reaction of $\mathrm{NHC}-\mathrm{Au}(\mathrm{I})-\mathrm{Cl} \mathbf{7}$ with $\mathbf{5} \mathbf{N M e}_{2}$ gave a complex mixture of products (8,9 and $\mathbf{1 0})$ arising from ligand exchange and anion scrambling (Scheme 3). ${ }^{11}$ 


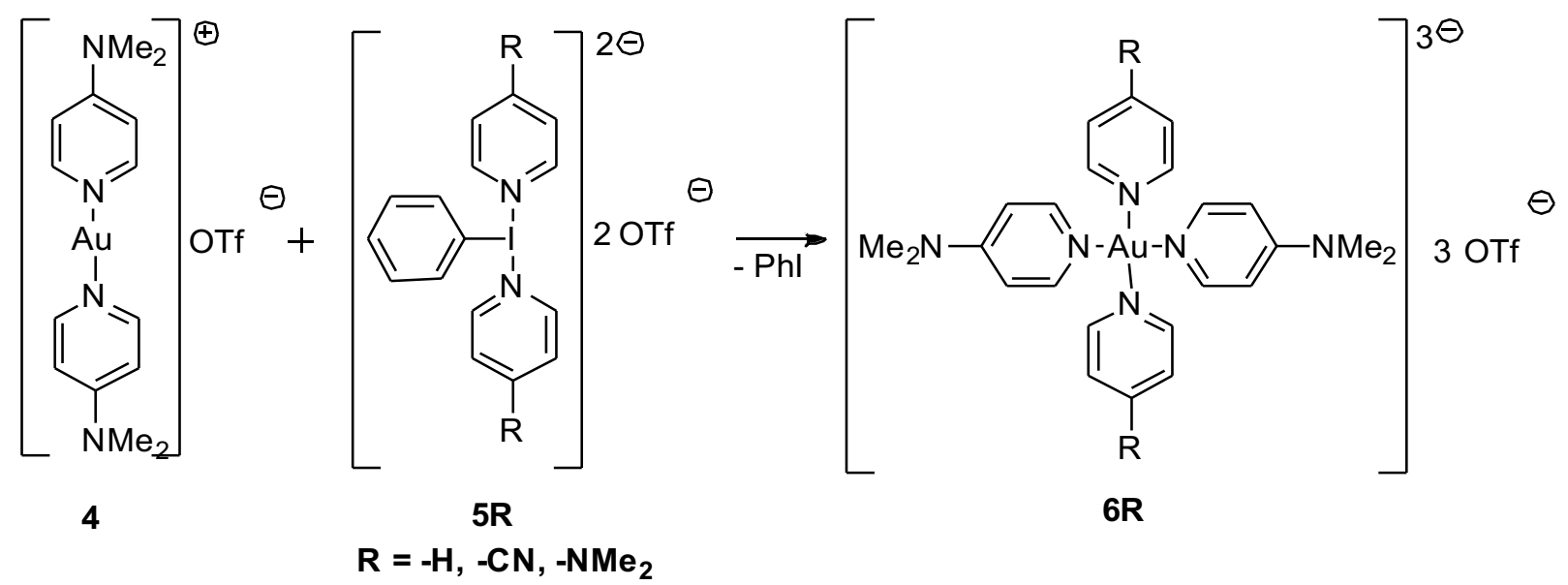

Scheme 2. Synthesis of tricationic Au(III) complexes.
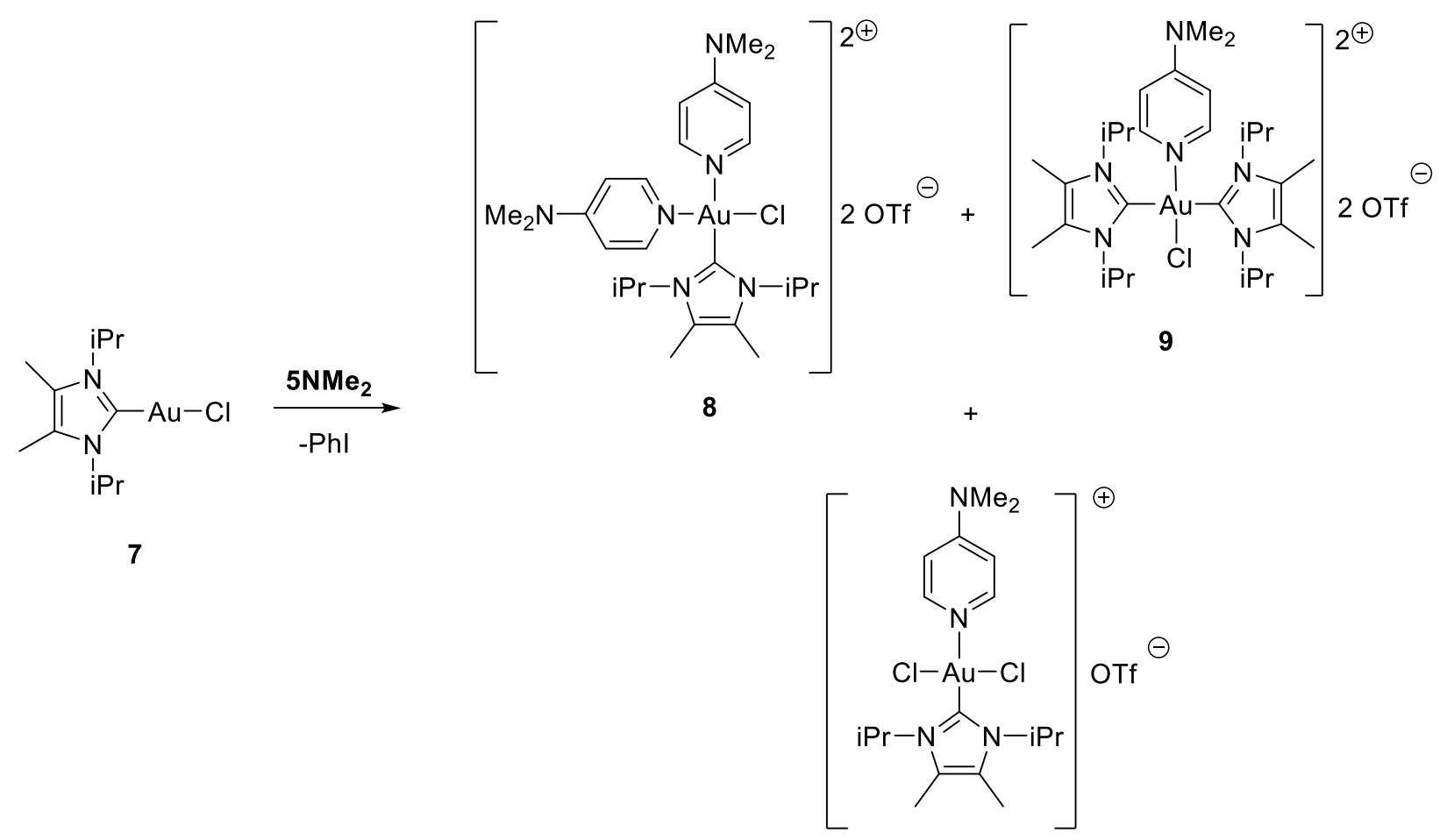

10

Scheme 3. Reaction of 7 with $5 \mathrm{NMe}_{2}$.

Previously our group reported that phosphine-containing $\operatorname{Ir}(\mathrm{I})$ (Vaska's complex) and $\mathrm{Rh}(\mathrm{I})$ (Wilkinson's catalyst) reacted with I(III) reagents also generally resulted in 
scrambling. These starting materials bear a chloride ligand as did 7. Reactions involving bidentate phosphines without halides went much more cleanly.

Direct reaction of $\mathrm{PPh}_{3}$ with $5 \mathrm{R}$ resulted in oxidation of the phosphine, generating dication 18, previously reported by Burford from halide abstraction/coordination reactions at chlorophosphonium cations. ${ }^{12-14}$

Based on these results, we hypothesized that scrambling is induced by the presence of a halide substituent, and have investigated the reactions of selected halide-free phosphine or $\mathrm{NHC}$ containing $\mathrm{Au}(\mathrm{I})$ complexes as well as $\mathrm{N}$-bound $\mathrm{Au}(\mathrm{I})$ complexes with 5R (Figure 1). The results show that oxidized phosphine and/or scrambling were observed in all phosphine-containing $\mathrm{Au}(\mathrm{l})$ complexes reactions. In the reaction of $\mathrm{N}$ bound $A u(I)$ complexes with $\mathbf{5 R}$, cationic $A u(I I I)$ compounds were generated in high yields and no scrambling was observed. For $A u(I)$ complexes without halides we are able to generate previously inaccessible mono-NHC-trispyridine trications.

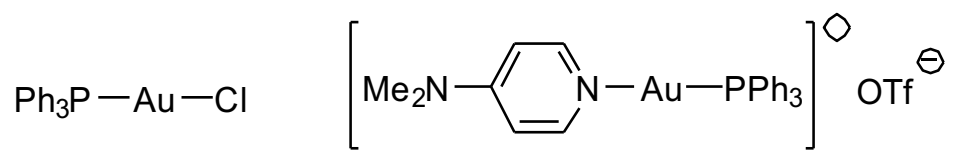

11

12

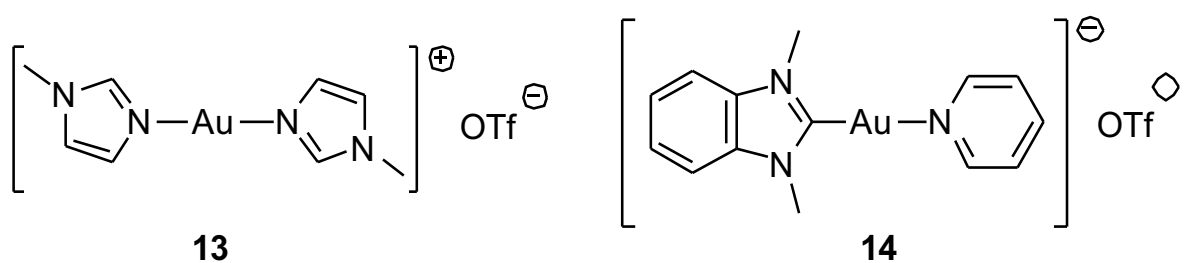

Figure 1. $A u(I)$ complexes used in this study. 


\section{Results and discussion}

\section{Reactions of phosphine gold complexes.}

Reaction of 11 with $5 \mathrm{NMe}_{2}$ in $\mathrm{CD}_{3} \mathrm{CN}$ resulted in a color change to orange within 10 minutes. The ${ }^{1} \mathrm{H}$ NMR spectrum of the reaction mixture indicated that there was a complex mixture of products present. The ${ }^{31} \mathrm{P}$ NMR spectrum of the reaction mixture gave 4 peaks $(65.6,57.6,33.0$ and $29.9 \mathrm{ppm})$ indicating the presence of four phosphorus containing products. The peaks at 65.6 and $57.6 \mathrm{ppm}$ are consistent with the reported compounds 18 and 19 respectively. ${ }^{12,15}$ The peaks at 33.0 and 29.9 are consistent with the gold compounds 11 and 17 respectively. ${ }^{16-17}$ Positive mode ESI-MS detection of a $\mathrm{CH}_{3} \mathrm{CN}$ solution of the reaction mixture gave fragments that could be identified at $[\mathrm{m} / \mathrm{z}]^{+}=510.4$ consistent with 15 and $[\mathrm{m} / \mathrm{z}]^{+}=440.8$ consistent with 16 (Scheme 4). The outcome of this reaction showed similar scrambling pattern to that observed in reaction of $\mathbf{7}$ with $\mathbf{5} \mathrm{NMe}_{2}$ with the addition of products apparently arising from reductive elimination reactions. 

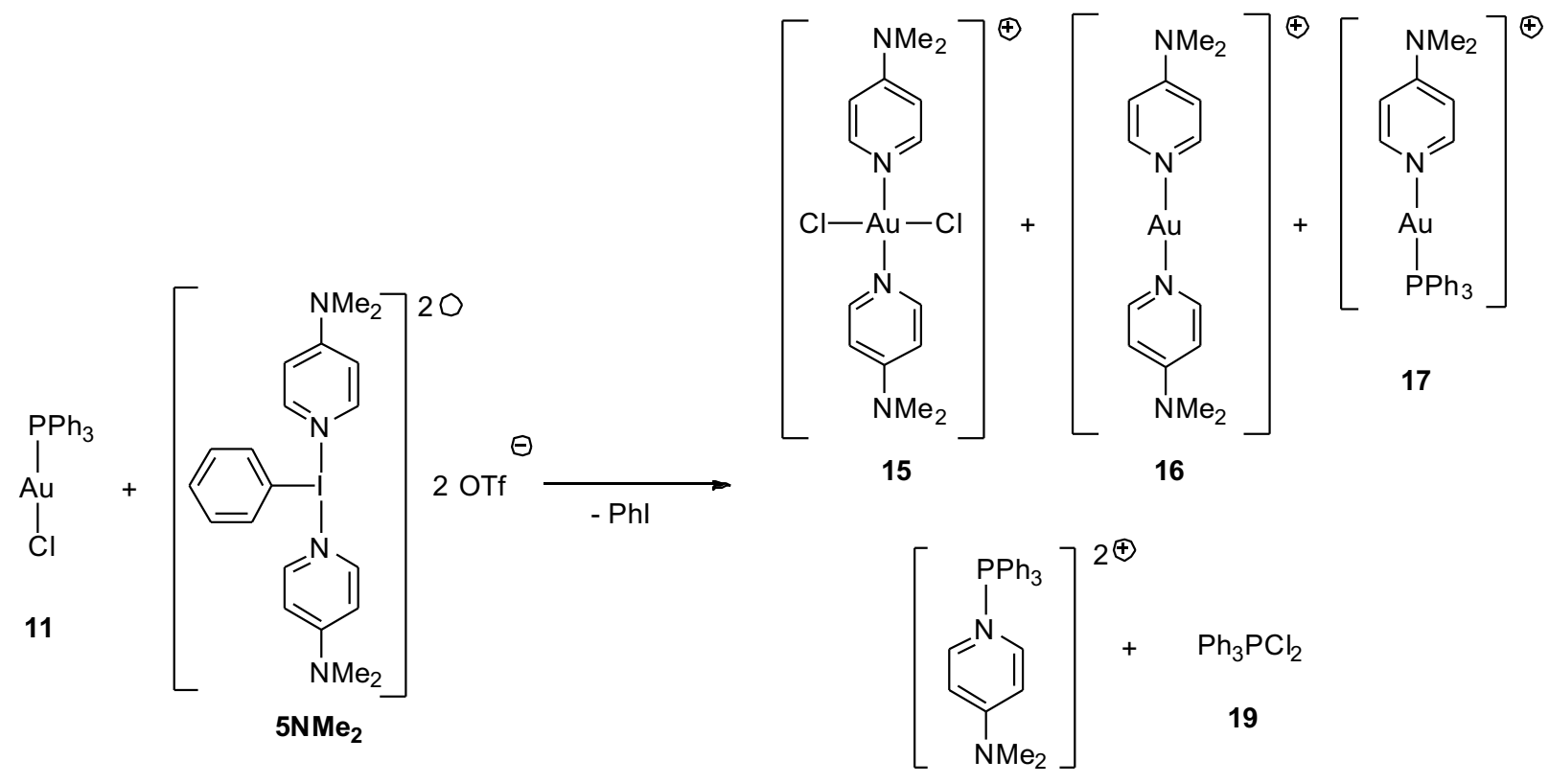

18

Scheme 4 . Reaction of $\mathbf{1 1}$ with $\mathbf{5} \mathrm{NMe}_{2}$ outcome as identified by mass spectrometry and ${ }^{31} \mathrm{P}$ NMR.

The reaction of 11 with $50 A c-O T f$ in a $1: 1$ ratio in $\mathrm{CHCl}_{3}$ resulted in a color change to yellow instantly (Scheme 5). The ${ }^{1} \mathrm{H}$ NMR spectrum of the mixture indicated the presence of iodobenzene and one other species. The ${ }^{31} \mathrm{P}$ NMR of the solution had one singlet at $52.1 \mathrm{ppm}$. Searching the literature for potential oxidized phosphine products revealed that $\left[\mathrm{Ph}_{3} \mathrm{P}-\mathrm{OTf}\right][\mathrm{OTf}]$ has been reported to give an identical chemical shift. ${ }^{12}$ The $\mathrm{Ph}_{3} \mathrm{PO}$ was not detected in the ${ }^{31} \mathrm{P}$ NMR of the crude reaction, but it can be rationalized by the reported behavior of $\left[\mathrm{Ph}_{3} \mathrm{P}-\mathrm{OTf}\right][\mathrm{OTf}]$ where an equilibrium between $\left[\mathrm{Ph}_{3} \mathrm{P}-\mathrm{OTf}\right][\mathrm{OTf}]$ and $\mathrm{Ph}_{3} \mathrm{PO}+$ triflic anhydride was observed. ${ }^{18-19}$ The positive ESI-MS detection of the mixture contained signal at $[\mathrm{m} / \mathrm{z}]^{+}=556.1$ corresponding to $\left[\left(\mathrm{Ph}_{3} \mathrm{PO}\right)_{2} \mathrm{H}\right]^{+}$. X-Ray diffraction studies were done on single crystals obtained from vapor diffusion of $\mathrm{Et}_{2} \mathrm{O}$ into concentrated $\mathrm{CH}_{2} \mathrm{Cl}_{2}$ solution revealed the crystal to be 
compound 20 which consists of two $\mathrm{Ph}_{3} \mathrm{PO}$ that are bridged with a proton and $\left[\mathrm{AuCl}_{4}\right]^{-}$ (Figure 2).

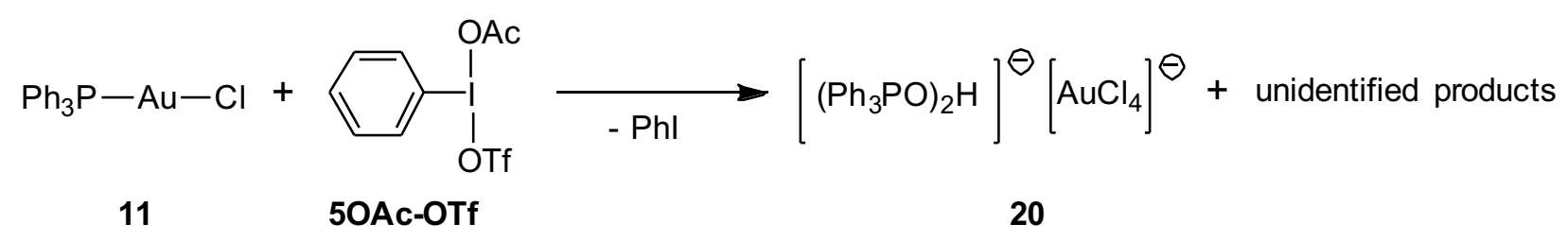

Scheme 5. Reaction of $\mathbf{1 1}$ with 5OAc-OTf outcome as identified by mass spectrometry, X-ray diffraction and ${ }^{31} \mathrm{P}$ NMR.

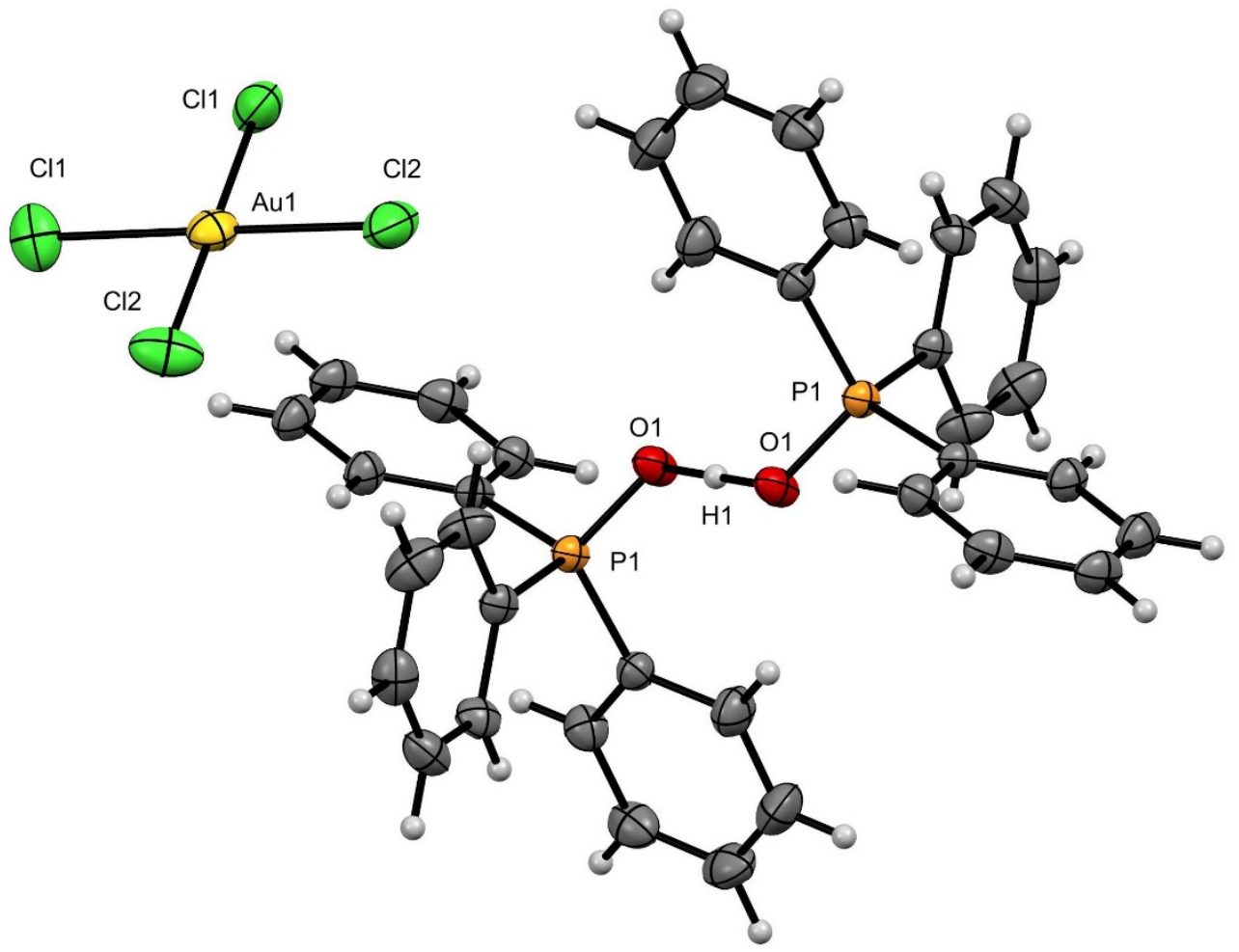

Figure 2. Solid-state structures of $\mathbf{2 0}$. Thermal ellipsoids are drawn at the $50 \%$ probability level. 
Treatment of compound $\mathbf{1 2}$ with $\mathbf{5} \mathbf{N M e}_{2}$ resulted in a color change to orange within 10 minutes. The ${ }^{31} \mathrm{P}$ NMR spectrum of the mixture contained signals at 57.6 and $26.6 \mathrm{ppm}$ which are consistent with compounds 18 and 22 respectively (Scheme 6). ${ }^{10,} 12$ The starting material (compound 12) was also detected in the ${ }^{31} \mathrm{P} N M R$ at $29.7 \mathrm{ppm}$ and in the cationic ESI mass spectrum of the reaction mixture $\left([\mathrm{m} / \mathrm{z}]^{+} 580.0\right)$. The fragment in the ESI mass spectrum at $[\mathrm{m} / \mathrm{z}]^{+}=440.8$ is consistent with 21 .

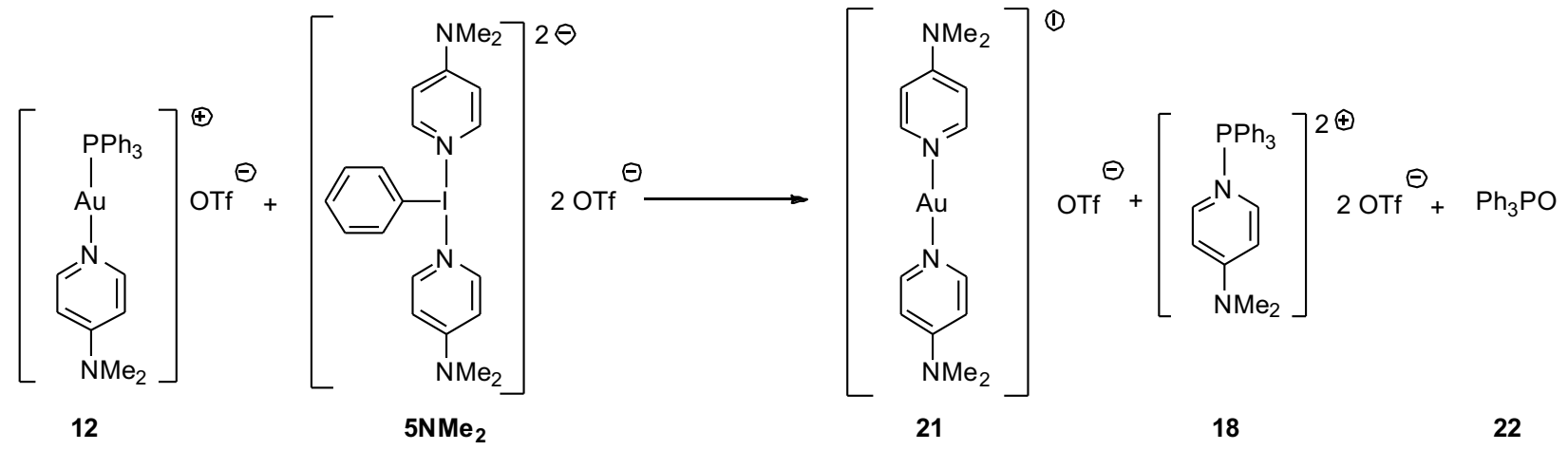

Scheme 6 . Reaction of $\mathbf{1 2}$ with $\mathbf{5} \mathrm{NMe}_{2}$ outcome as identified by mass spectrometry and ${ }^{31} \mathrm{P}$ NMR.

The reaction of 12 with 50Ac-OTf resulted in color change to yellow instantly followed by the formation of a black solid. The ${ }^{31} \mathrm{P}$ NMR of the reaction mixture gave signals at 52.1 ppm representing $\left[\mathrm{Ph}_{3} \mathrm{P}-\mathrm{OTf}\right][\mathrm{OTf}]$ and $27.8 \mathrm{ppm}$ representing compound 22 . Positive mode ESI-MS detection of a $\mathrm{CH}_{3} \mathrm{CN}$ solution of the reaction mixture gave fragments that could be identified at $[\mathrm{m} / \mathrm{z}]^{+}=556.2$ consistent with $\left[\left(\mathrm{PPh}_{3} \mathrm{O}\right)_{2} \mathrm{H}\right]^{+}$and $[\mathrm{m} / \mathrm{z}]^{+}=499.4$ consistent with $\left[\mathrm{Au}\left(\mathrm{PPh}_{3}\right)\left(\mathrm{CH}_{3} \mathrm{CN}\right)\right]^{+}$. 
It's evident that the reactions of phosphine-containing gold(I) complexes with the selected I(III) resulted in the oxidation of $\mathrm{PPh}_{3}$ and no phosphine-Au(III) complexes were isolated. Reaction of 12 with $\mathrm{PhICl}_{2}(5 \mathrm{Cl})$ was not attempted as this reaction (using pyridine-Au(I) instead of 4-DMAP-Au(I) as starting material) was previously reported and gave similar scrambling patterns to what has been observed in our reactions. ${ }^{10}$

\section{Reactions of $\mathrm{N}$-imidazole $\mathrm{Au}(\mathrm{I})$ complexes}

The $A u(I)$ starting complex 13 was achieved via adapting the synthetic protocol of $\operatorname{Lin}^{20}$ and using N-methylimidazole as the ligand in place of 4-DMAP (Scheme 7). The same cation has previously been reported as an $\left[\mathrm{AuCl}_{2}\right]^{-}$salt. ${ }^{21}$ Compound 13 has a linear structure with normal Au-N bond lengths and they are lined parallel with a Au-Au contact of about $3.26 \AA$ (Figure 3).

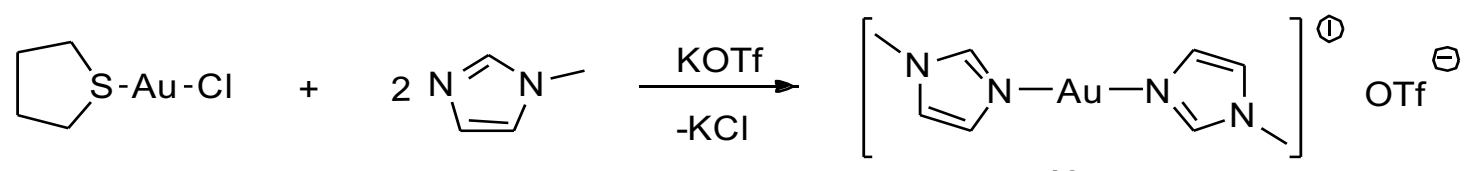

Scheme 7 . Synthesis of compound 13

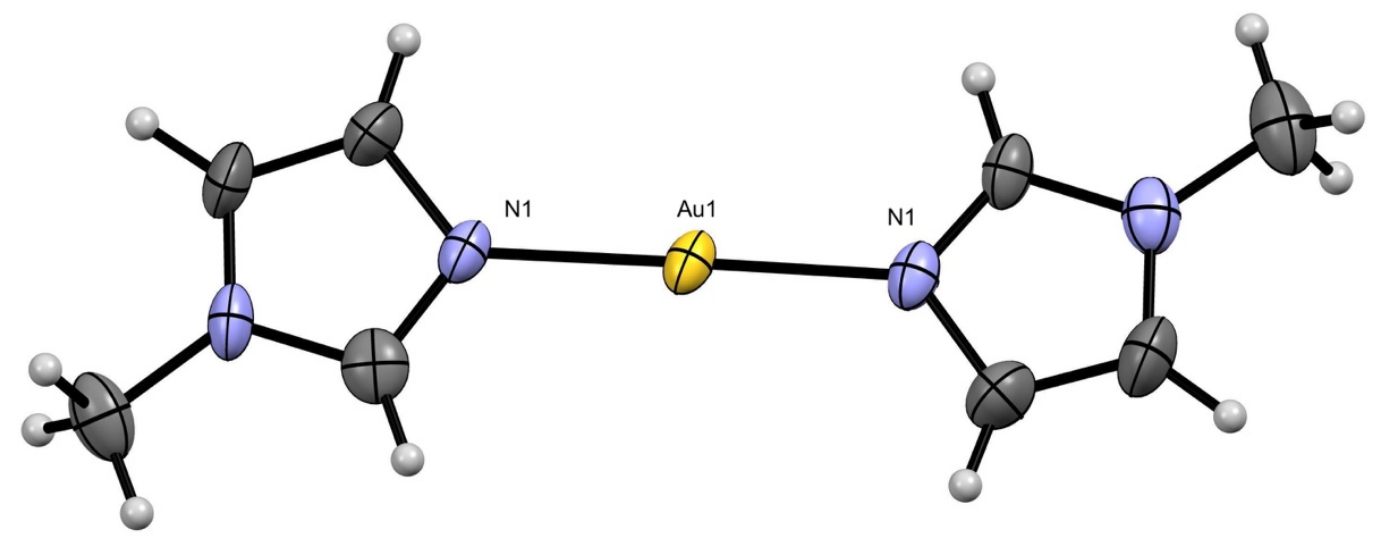


Figure 3. Solid-state structures of 13 . Thermal ellipsoids are drawn at the $50 \%$ probability level. Anions and solvate were omitted for clarity (OTf, $\mathrm{CH}_{3} \mathrm{CN}$ ). Selected bond distances $(\AA)$ Au1-N1 2.000(7).

Reaction of 13 with $5 \mathrm{Cl}$ in $\mathrm{CH}_{2} \mathrm{Cl}_{2}$ resulted in the formation of a yellow solid. The solid was filtered and washed with $\mathrm{CH}_{2} \mathrm{Cl}_{2} .{ }^{1} \mathrm{H}$ NMR analysis of the solid in $\mathrm{CD}_{3} \mathrm{CN}$ gave a set of resonances consistent with a single $\mathrm{N}$-methylimidazole containing product (Scheme 8). Mass spectrometry in $\mathrm{CH}_{3} \mathrm{CN}$ showed signals arising from compound $\mathbf{2 3}$ which was further confirmed by X-Ray diffraction studies on single crystals obtained from vapor diffusion of $\mathrm{Et}_{2} \mathrm{O}$ into concentrated $\mathrm{CH}_{3} \mathrm{CN}$ solution of the isolated solid (Figure 4).

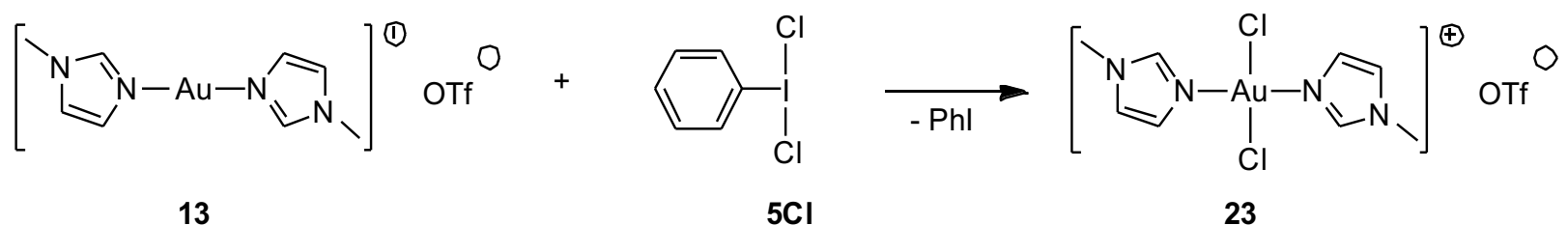

Scheme 8. Synthesis of compound 23.

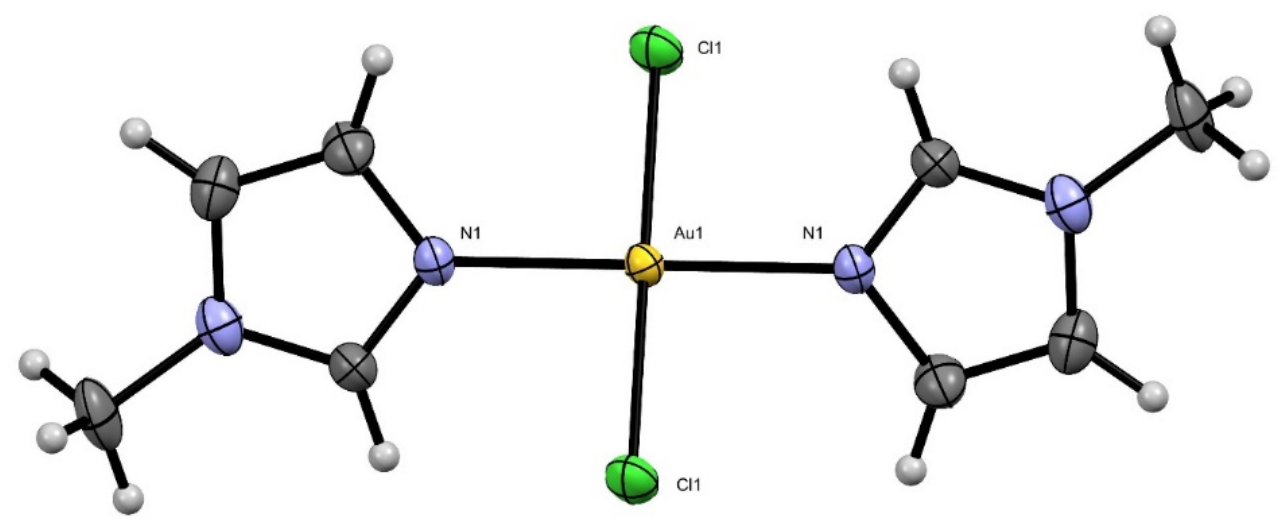


Figure 4. Solid-state structures of 23. Thermal ellipsoids are drawn at the $50 \%$ probability level. Anions and solvate were omitted for clarity (OTf, $\left.\mathrm{CH}_{3} \mathrm{CN}\right)$. Selected bond distances $(\AA)$ Au1-N1 2.007(6), Au1-Cl1 2.277(17).

Reaction of 13 with 5IM in $\mathrm{CH}_{3} \mathrm{CN}$ (Scheme 9) resulted in a color change to yellow within 5 minutes. The solvent was removed under reduced pressure to give a pale yellow solid. The solid was then recrystallized from $\mathrm{CH}_{3} \mathrm{CN} / \mathrm{Et}_{2} \mathrm{O}$.

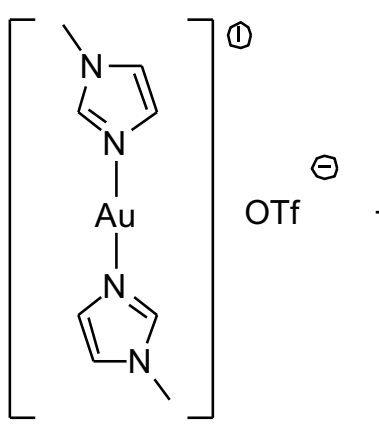

13

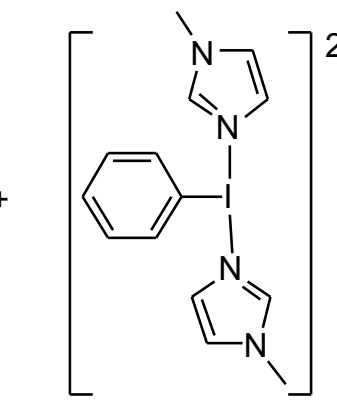

$5 \mathrm{IM}$

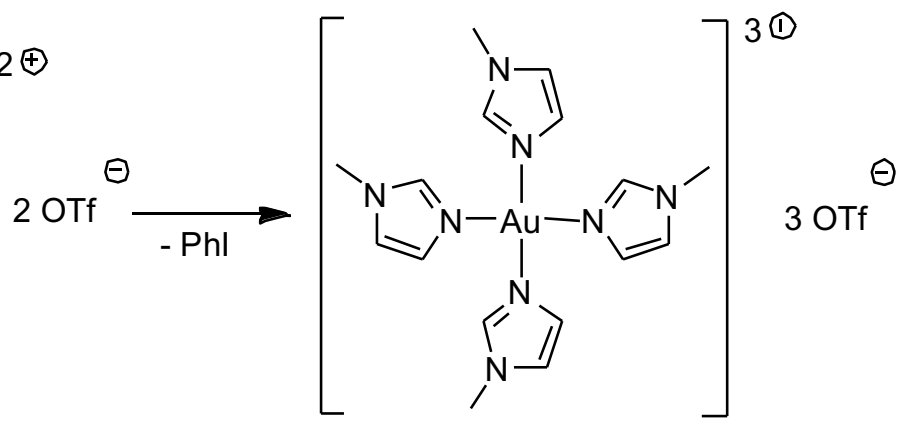

24

Scheme 9. Synthesis of compound 24.

${ }^{1} \mathrm{H}$ NMR spectroscopy was consistent with a single compound containing $\mathrm{N}$ methylimidazole. The signal at $[\mathrm{m} / \mathrm{z}]^{+}=823.1$ in the positive ESI-MS spectrum of the mixture corresponds to $\left[\mathrm{Au}(\mathrm{N} \text {-methylimidazole })_{4} 2 \mathrm{OTf}\right]^{+}$. Single crystals were grown from a $\mathrm{CH}_{3} \mathrm{CN}$ solution of the compound via slow vapor diffusion of $\mathrm{Et}_{2} \mathrm{O}$ and subsequent X-ray diffraction studies confirmed homoleptic compound 24 (Figure 5), which is isolated in $79 \%$ yield. This compound is the second example of homoleptic Nimidazole containing $\mathrm{Au}(\mathrm{III})$ trications. The first reported example incorporated an extended Au-ligand framework for the synthesis of Au nanoparticles. ${ }^{22}$ 


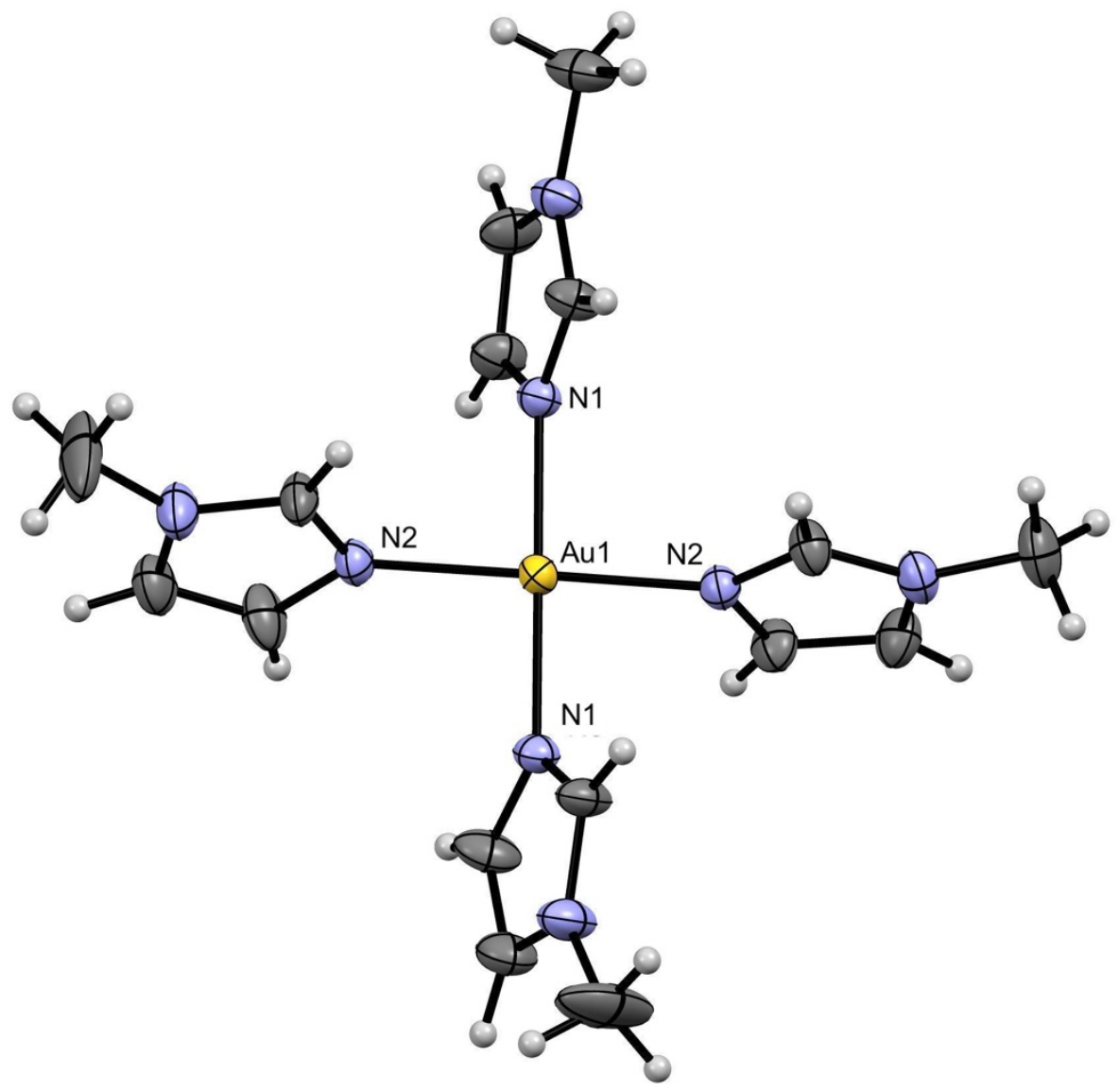

Figure 5. Solid-state structures of 24 . Thermal ellipsoids are drawn at the $50 \%$ probability level. Anions and solvate were omitted for clarity (OTf, $\left.\mathrm{CH}_{3} \mathrm{CN}\right)$. Selected bond distances ( $\AA$ ) Au1-N1 1.996(3), Au1-N2 1.999(3).

Using I(III) oxidant $\mathbf{5 R}$ resulted in the corresponding pseudo-homoleptic compounds $25 \mathrm{H}, 25 \mathrm{CN}$ and $25 \mathrm{NMe}_{2}$ respectively in good yields (Scheme 10). In previous work we reported the synthesis and the use of $25 \mathrm{CN}$ in generating difluorogold(III) complexes but the crystal structure was not reported. ${ }^{23}$ The solid state structures of compounds $25 \mathrm{H}$ and $25 \mathrm{CN}$ are depicted in Figures 6 and 7 . Unfortunately no crystals of diffraction quality could be obtained for compound $25 \mathrm{NMe}_{2}$. 
The reaction of 5OAc-OTf with 13 in $\mathrm{CHCl}_{3}$ resulted in a decomposition of the $\mathrm{Au}$ complex which was indicated by the formation of black solid.

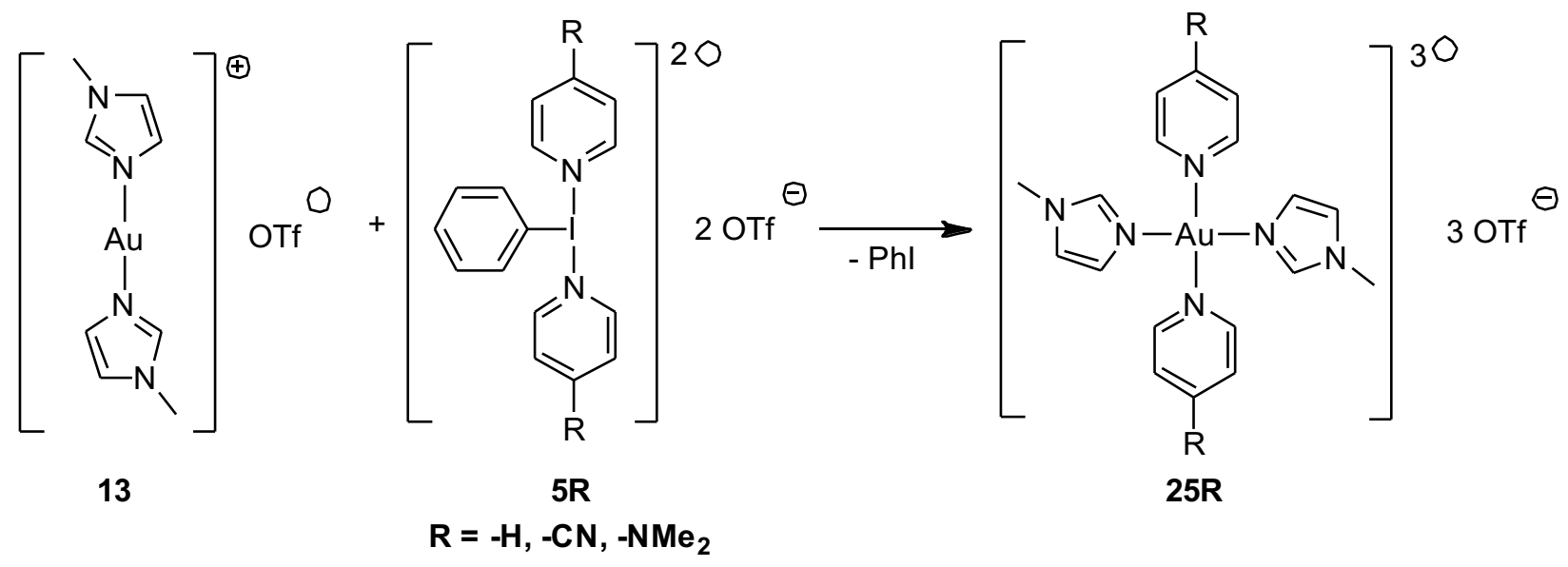

Scheme 10. Synthesis of $\mathrm{Au}(\mathrm{III})$ trications $\mathbf{2 5 R}$.

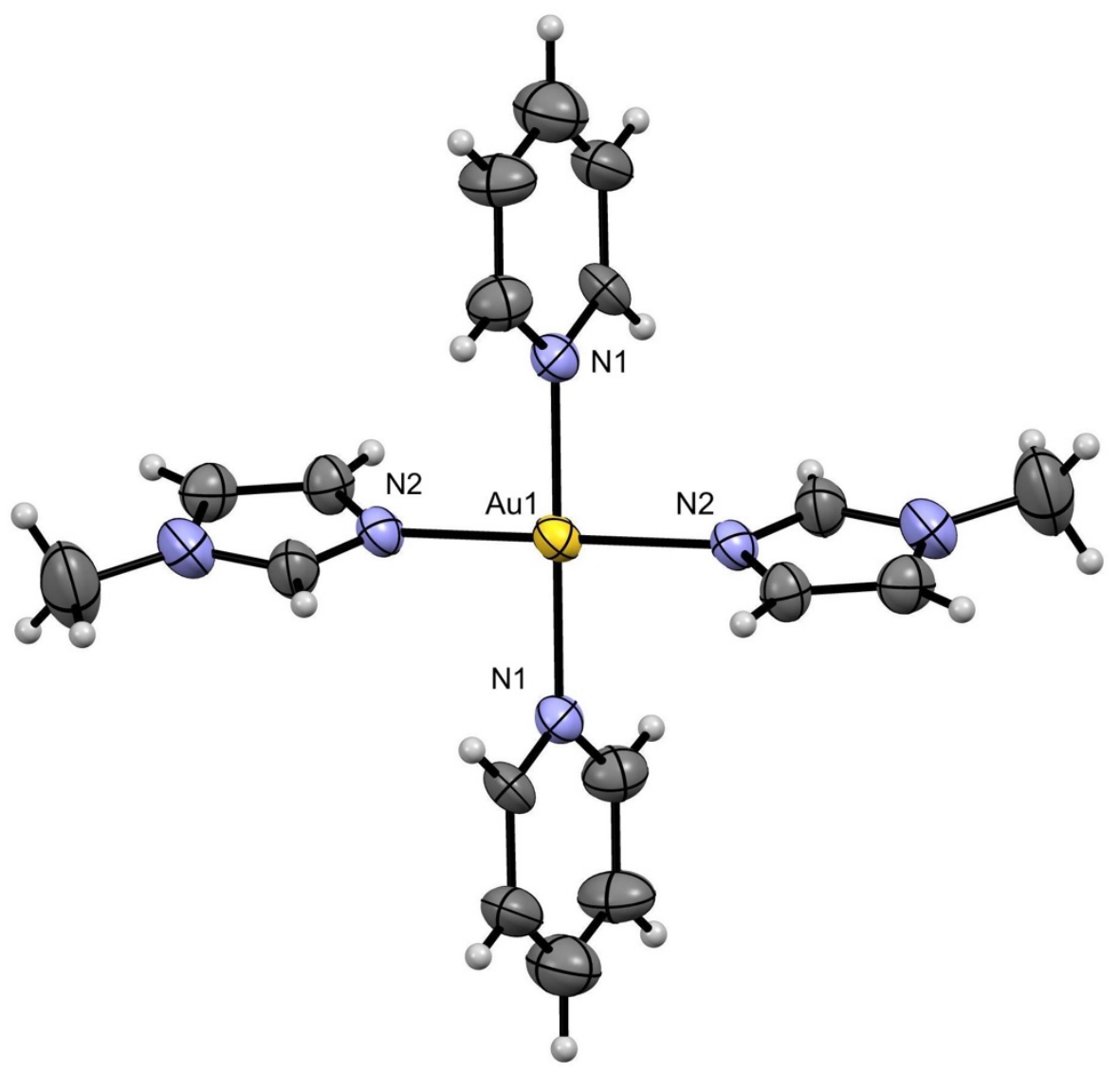


Figure 6. Solid-state structures of $\mathbf{2 5 H}$. Thermal ellipsoids are drawn at the $50 \%$ probability level. Anions and solvate were omitted for clarity (OTf, $\left.\mathrm{CH}_{3} \mathrm{CN}\right)$. Selected bond distances ( $\AA$ ) Au1-N1 2.016(5), Au1-N2 2.009(4).

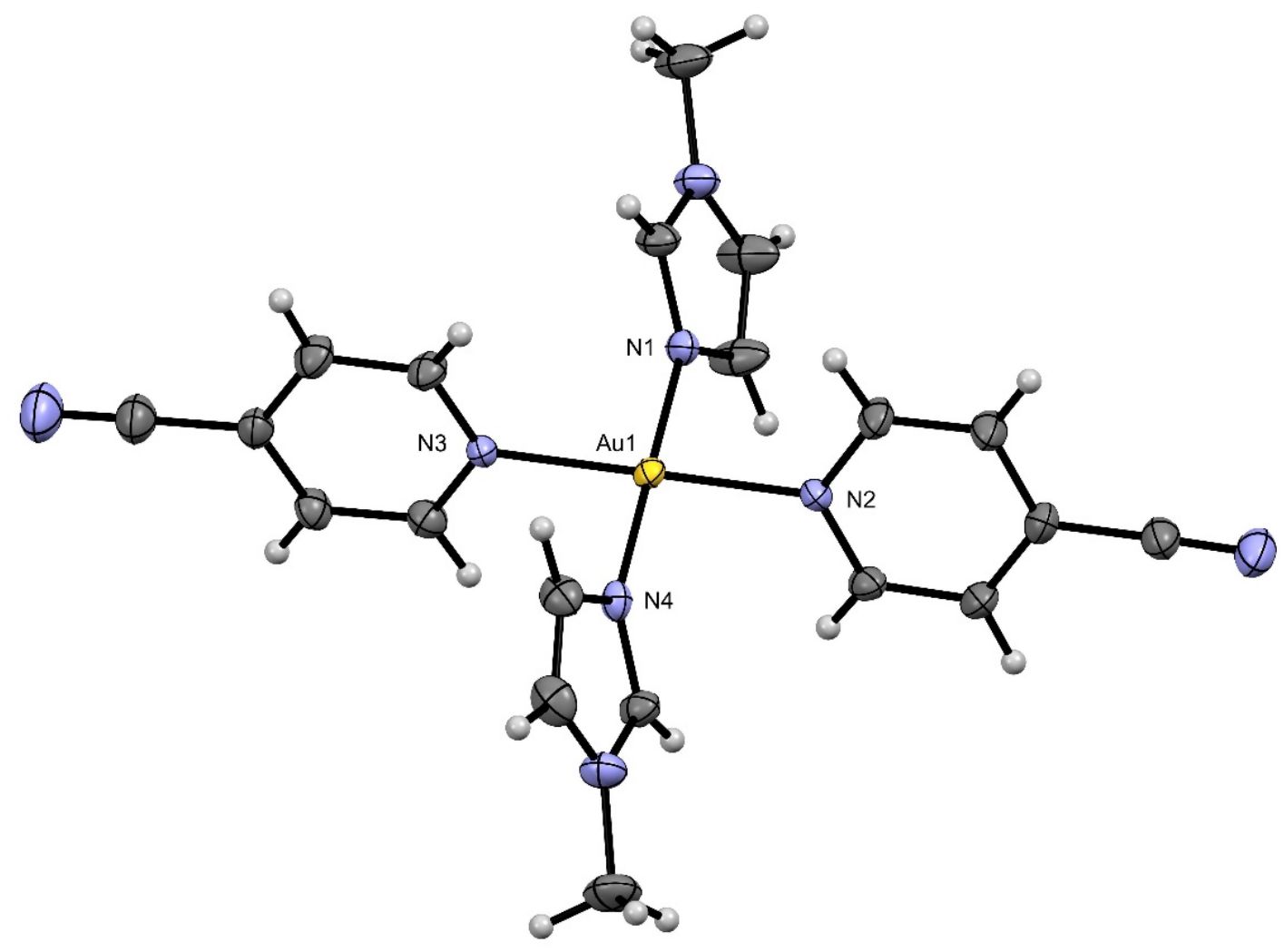

Figure 7. Solid-state structures of $\mathbf{2 5 C N}$. Thermal ellipsoids are drawn at the $50 \%$ probability level. Anions and solvate were omitted for clarity (OTf, $\left.\mathrm{CH}_{3} \mathrm{CN}\right)$. Selected bond distances ( $\AA$ ) Au1-N1 2.006(4), Au1-N2 2.035(4), Au1-N3 2.024(4), Au1-N4 1.991(4). 
The starting complex 14 was synthesized using the standard synthetic protocol of de Frémont ${ }^{10}$ and using 1,3-dimethylbenzimidazolium as the ligand (Scheme 11). The solid state structure of $\mathbf{1 4}$ is shown in Figure 8.

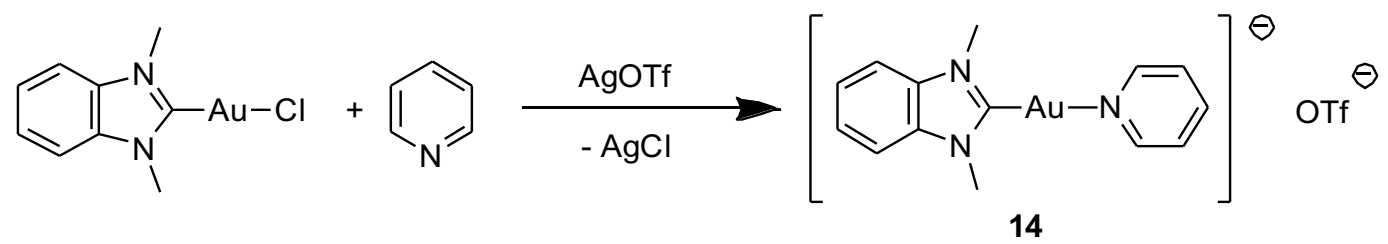

Scheme 11. Synthesis of compound 14.

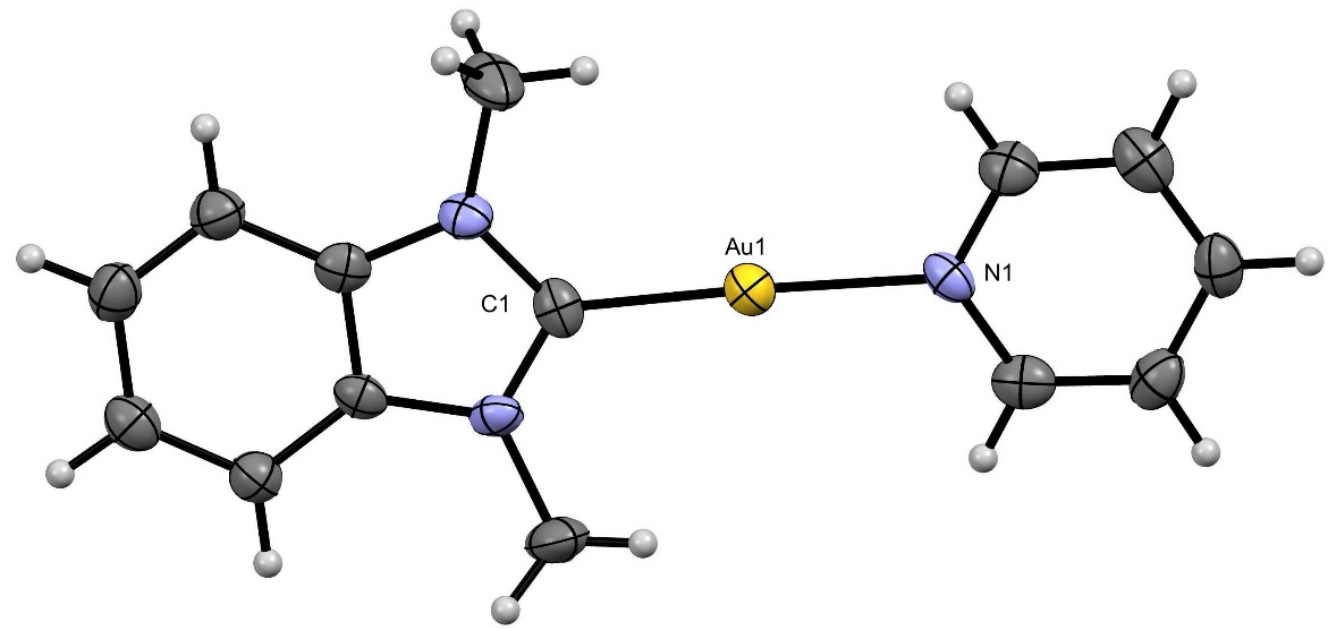

Figure 8. Solid-state structures of 14 . Thermal ellipsoids are drawn at the $50 \%$ probability level. Anions and solvate were omitted for clarity (OTf, $\left.\mathrm{CH}_{3} \mathrm{CN}\right)$. Selected bond distances ( $\AA$ ) Au1-N1 2.052(5), Au1-C1 1.975(7).

Reaction of 14 with $\mathrm{PhICl}_{2}$ was not attempted as similar reactions were previously reported on $\mathrm{Au}(\mathrm{I})$ compounds with different $\mathrm{NHC}$ ligands. ${ }^{10}$ Treatment of compound 14 with $5 \mathrm{H}$ in $\mathrm{CD}_{3} \mathrm{CN}$ at room temperature for 30 minutes followed by workup resulted in the isolation of a yellow solid. The ${ }^{1} \mathrm{H}$ NMR spectroscopy of the isolated solid was consistent with a single compound containing one 1,3-dimethylbenzimidazole and three 
pyridine ligands (Scheme 12). The positive ESI-MS detection of the mixture indicated the presence of 26 at $[\mathrm{m} / \mathrm{z}]^{+}=877.8$ as monocationic $\left[\mathrm{Au}(\mathrm{NHC})(\text { pyridine })_{3} 2 \mathrm{OTf}\right]^{+}$.

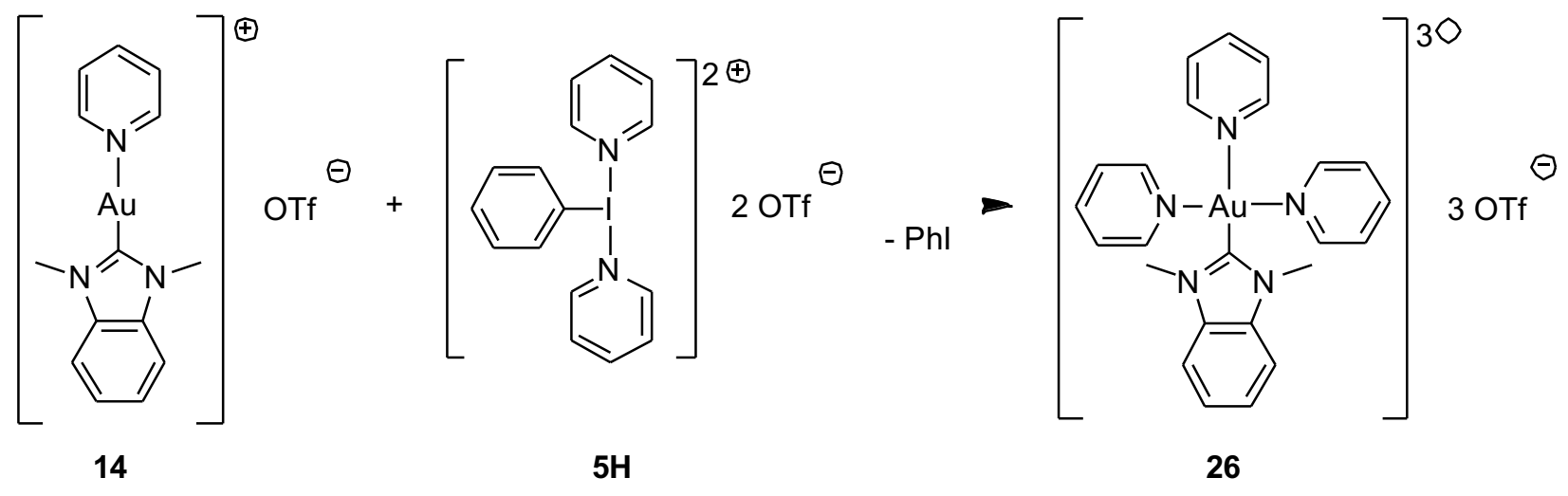

Scheme 12. Synthesis of compound 26.

X-Ray diffraction studies were done on single crystals obtained from vapor diffusion of $\mathrm{Et}_{2} \mathrm{O}$ into concentrated $\mathrm{CH}_{3} \mathrm{CN}$ solution of the isolated solid confirmed the compound to be 26 .

Reaction of 14 with 5OAc-OTf in $\mathrm{CDCl}_{3}$ resulted in the formation of black solid due to decomposition of Au complex.

The synthesis of $\mathrm{Au}(\mathrm{III})$ cationic complexes (23-26) was achieved in good yield and purity. Prior attempts to generate tricationic $A u(I I I)$ compounds using silver salts to replace two chlorides from $\mathrm{Au}(\mathrm{III})$ compounds with pyridine ligands resulted in complex decomposition demonstrating the ability of $\mathrm{I}(\mathrm{III})$ reagents in cleanly oxidizing $\mathrm{N}$-bound $\mathrm{Au}(\mathrm{I})$ complexes. ${ }^{10}$ 


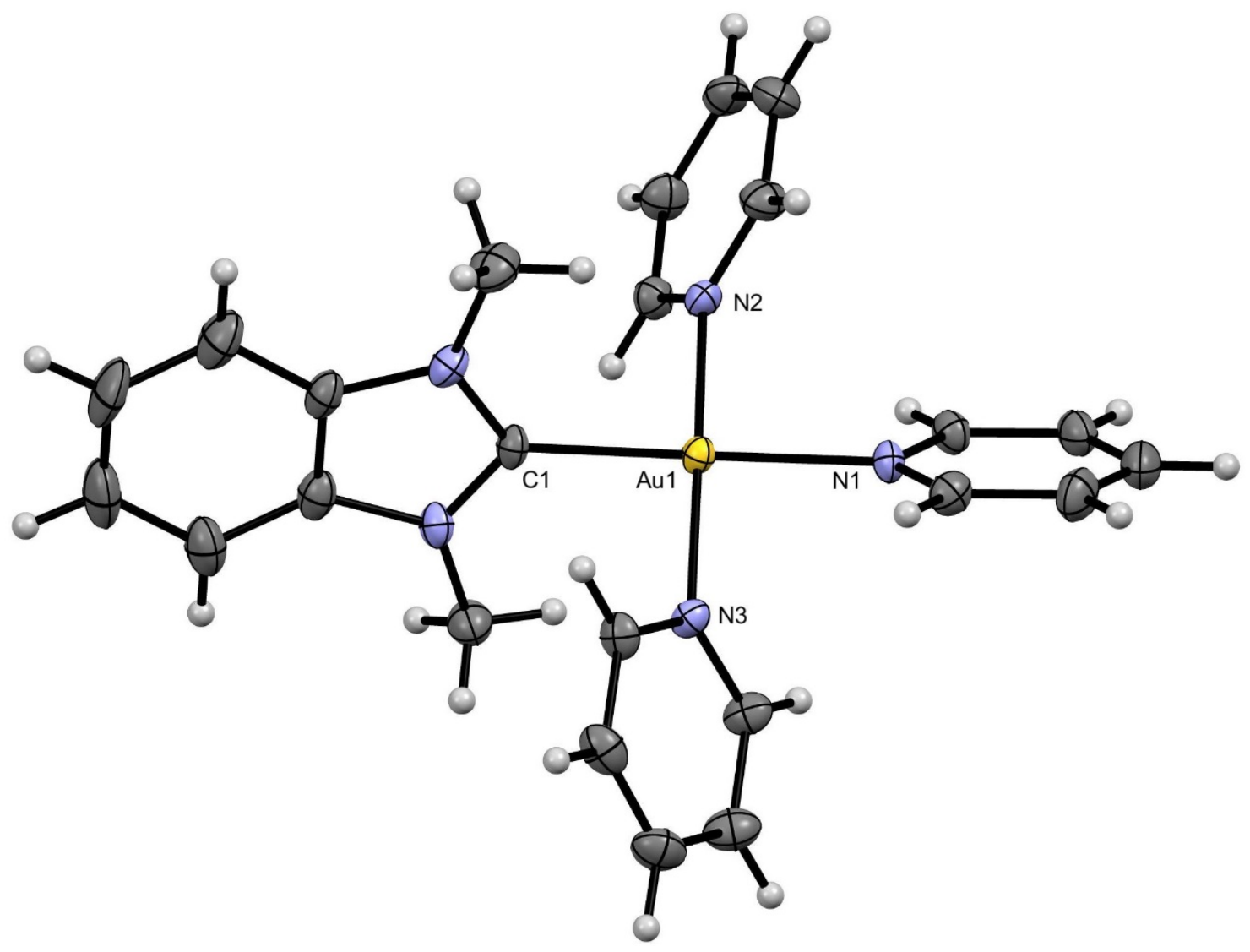

Figure 9. Solid-state structures of 26 . Thermal ellipsoids are drawn at the $50 \%$ probability level. Anions and solvate were omitted for clarity (OTf, $\left.\mathrm{CH}_{3} \mathrm{CN}\right)$. Selected bond distances $(\AA)$ Au1-N1 2.085(3), Au1-N2 2.025(3), Au1-N3 2.021(3), Au1-C1 2.032(3).

\section{Conclusion}

This work described the synthesis of a series of cationic Au(III) complexes. Oxidative addition to $\mathrm{N}$-bound $\mathrm{Au}(\mathrm{I})$ complex (13) using I(III) reagents resulted in homoleptic and pseudo-homoleptic $\mathrm{Au}(\mathrm{III})$ complexes in high yields. The reaction of $\mathbf{5 H}$ with $\mathbf{1 4}$ generated mono-NHC-trispyridine $\mathrm{Au}(\mathrm{III})$ trications. In contrast, reactions of $\mathrm{I}(\mathrm{III})$ reagents with Phosphine-containing $A u(l)$ complexes resulted in the oxidation of 
phosphine and/or ligand scrambling.

\section{Experimental procedures}

Solvents were obtained from Caledon Laboratories and dried using an Innovative Technologies Solvent Purification System with dual columns packed with alumina. The dried solvents were stored under an $\mathrm{N}_{2}$ atmosphere over $3 \AA$ molecular sieves in the glovebox. Solvents used for NMR spectroscopy were purchased from Cambridge Isotopes or Sigma-Aldrich and were dried with $\mathrm{CaH}_{2}$ and stirred for 2 days and distilled and then stored in the glove box over $3 \AA$ molecular sieves. Compounds $11,{ }^{24} 12,{ }^{17} 13,{ }^{20}$ $14,{ }^{10} \mathbf{5} \mathrm{Cl}^{25}$ and $5 \mathbf{R}^{26}$ were synthesised via literature procedures. Gold powder was purchased from Precious Metals Online. All other reagents were purchased from Alfa Aesar or Sigma Aldrich and used as received.

Reaction of 11 with $5 \mathrm{NMe}_{2}$. A solution of $5 \mathrm{NMe}_{2}(82 \mathrm{mg}, 0.11 \mathrm{mmol})$ in $3 \mathrm{~mL}$ $\mathrm{CD}_{3} \mathrm{CN}$ was added drop wise to $11(50 \mathrm{mg}, 0.10 \mathrm{mmol})$ in $3 \mathrm{~mL} \mathrm{CD}_{3} \mathrm{CN}$. The mixture was stirred for 3 hours resulting in a color change to orange. Aliquot was removed for NMR and mass spectrometry analysis. ${ }^{31} \mathrm{P}$ NMR (162 MHz, $\left.\mathrm{CDCl}_{3}\right) \delta(\mathrm{ppm}): 65.6(\mathrm{~s})$, 57.6 (s), 33.0 (s), 29.9 (s). ESI-MS [M] $]^{n+}: \mathrm{m} / \mathrm{z} 273.8\left[\mathrm{Au}\left(\mathrm{CH}_{3} \mathrm{CN}\right) \mathrm{Cl}\right]^{+}, 440.8[\mathrm{Au}(4-$ dmap $\left.)_{2}\right]^{+}, 510.4\left[\mathrm{Au}(4-\mathrm{dmap})_{2} \mathrm{Cl}_{2}\right]^{+}$. See supporting information for ${ }^{1} \mathrm{H}$ NMR.

Reaction of 11 with 50Ac-OTf. A mixture of diacetoxyiodobenzene (20.6 mg, 0.064 $\mathrm{mmol}$ ) and TMS-OTf $(23.3 \mu \mathrm{L}, 0.128 \mathrm{mmol})$ in $2 \mathrm{~mL} \mathrm{CHCl}_{3}$ was added drop wise to a solution of $11(30 \mathrm{mg}, 0.061 \mathrm{mmol})$ in $2 \mathrm{~mL} \mathrm{CHCl} 3$. The mixture was stirred for 30 minutes resulting in a yellow mixture and a black solid. The solid was filtered and the 
filtrate was collected. Solvent removed under reduced pressure to give a yellow solid which was washed with $\mathrm{Et}_{2} \mathrm{O} .{ }^{31} \mathrm{P}$ NMR (162 MHz, $\mathrm{CD}_{3} \mathrm{CN}$ ) $\delta$ (ppm): 52.1 (s). ESI-MS $[\mathrm{M}]^{\mathrm{n}+}: \mathrm{m} / \mathrm{z} 273.8\left[\mathrm{Au}\left(\mathrm{CH}_{3} \mathrm{CN}\right) \mathrm{Cl}\right]^{+}, 556.1\left[\left(\mathrm{Ph}_{3} \mathrm{PO}\right)_{2} \mathrm{H}\right]^{+} .{ }^{1} \mathrm{H}$ NMR $\left(400 \mathrm{MHz}, \mathrm{CD}_{3} \mathrm{CN}\right): \delta$ $(\mathrm{ppm})=$ 7.91-7.87 $(\mathrm{m}), 7.78-7.70(\mathrm{~m})$.

Reaction of 12 with $5 \mathrm{NMe}_{2} . \quad$ A solution of $5 \mathrm{NMe}_{2}(52 \mathrm{mg}, 0.070 \mathrm{mmol})$ in $2 \mathrm{~mL}$ $\mathrm{CH}_{3} \mathrm{CN}$ was added to a solution of $12(50 \mathrm{mg}, 0.068 \mathrm{mmol})$ in $2 \mathrm{~mL} \mathrm{CH}_{3} \mathrm{CN}$ drop wise. The mixture was stirred for 3 hours resulting in an orange solution. Solvent removed under reduced pressure and the resulting orange solid was washed with $\mathrm{Et}_{2} \mathrm{O}$. ${ }^{31} \mathrm{P} \mathrm{NMR}$ (162 MHz, CD $\left.{ }_{3} \mathrm{CN}\right) \delta(p p m): 57.6$ (s), 29.7 (s), 26.6 (s). ESI-MS [M] ${ }^{\mathrm{n}+}: \mathrm{m} / \mathrm{z} 395.0$ $\left[\mathrm{Ph}_{3} \mathrm{P}\right]^{2+}[\mathrm{Tf}]^{-}, 440.8\left[\mathrm{Au}(4-\mathrm{dmap})_{2}\right]^{+}, 499.4\left[\mathrm{Au}\left(\mathrm{PPh}_{3}\right)\left(\mathrm{CH}_{3} \mathrm{CN}\right)\right]^{+}, 580.0\left[\mathrm{Au}\left(\mathrm{PPh}_{3}\right)(4-\right.$ dmap) $]^{+}, 736.2\left[\mathrm{Au}\left(\mathrm{PPh}_{3}\right)\left(\mathrm{Ph}_{3} \mathrm{PO}\right)\right]^{+}$. See supporting information for ${ }^{1} \mathrm{H} \mathrm{NMR}$.

Reaction of 12 with 50Ac-OTf. A mixture of diacetoxyiodobenzene (20.6 mg, 0.064 $\mathrm{mmol})$ and TMS-OTf $(23.3 \mu \mathrm{L}, 0.128 \mathrm{mmol})$ in $2 \mathrm{~mL} \mathrm{CHCl} 3$ was added drop wise to 12 (45 mg, $0.062 \mathrm{mmol}$ ) in $2 \mathrm{~mL} \mathrm{CHCl} 3$ and stirred for 30 minutes. The resulting black solid was filtered, and aliquot of the filtrate was removed for NMR and mass spectrometry analysis. ${ }^{31} \mathrm{P}$ NMR $\left(162 \mathrm{MHz}, \mathrm{CHCl}_{3}\right) \delta$ (ppm): 52.1 (s), 27.8 (s). ESI-MS [M] $: \mathrm{m} / \mathrm{z}$ $556.2\left[\left(\mathrm{PPh}_{3} \mathrm{O}\right)_{2} \mathrm{H}\right]^{+}, 499.4\left[\mathrm{Au}\left(\mathrm{PPh}_{3}\right)\left(\mathrm{CH}_{3} \mathrm{CN}\right)\right]^{+}$.

Synthesis of 13 . N-methylimidazole $(175 \mu \mathrm{L}, 2.20 \mathrm{mmol})$ was added to a dichloromethane solution $(20 \mathrm{~mL})$ containing tht-AuCl $(350 \mathrm{mg}, 1.09 \mathrm{mmol})$ and $\mathrm{KOTf}$ (210 $\mathrm{mg}, 1.12 \mathrm{mmol})$. The mixture was stirred for 24 hours in the dark. The solvent was removed under vacuum to give a light yellow solid. The solid was washed with $\mathrm{Et}_{2} \mathrm{O}$ and 
recrystallized from $\mathrm{CH}_{2} \mathrm{Cl}_{2} / \mathrm{Et}_{2} \mathrm{O}$ to give a white solid (457 mg, 82\%). ${ }^{1} \mathrm{H}$ NMR (400 $\left.\mathrm{MHz}, \mathrm{CDCl}_{3}\right): \delta(\mathrm{ppm})=8.26(\mathrm{~s}, 2 \mathrm{H}), 7.13(\mathrm{~s}, 2 \mathrm{H}), 7.05(\mathrm{~s}, 2 \mathrm{H}), 3.84(\mathrm{~s}, 6 \mathrm{H}) \cdot{ }^{13} \mathrm{C} \mathrm{NMR}$ $\left(100 \mathrm{MHz}, \mathrm{CDCl}_{3}\right): \delta(\mathrm{ppm})=141.00,129.44,121.71,35.23$. ESI-MS [M] ${ }^{+}: \mathrm{m} / \mathrm{z} 361$ $\left[\mathrm{Au}(\mathrm{N}-\text { methylimidazole })_{2}\right]^{+}$.

Synthesis of 23. A solution of $5 \mathrm{Cl}(27 \mathrm{mg}, 0.098 \mathrm{mmol})$ in $2 \mathrm{~mL} \mathrm{CH}_{2} \mathrm{Cl}_{2}$ was added drop wise to a solution of $13(50 \mathrm{mg}, 0.098 \mathrm{mmol})$ in $2 \mathrm{~mL} \mathrm{CH}{ }_{2} \mathrm{Cl}_{2}$. The mixture was then stirred for 30 minutes resulting in a yellow solid. The solid was filtered, washed with $\mathrm{CH}_{2} \mathrm{Cl}_{2}(3 \times 3 \mathrm{~mL})$ and dried in vacuo $\left(49 \mathrm{mg}, 85\right.$ yield). ${ }^{1} \mathrm{H} \mathrm{NMR}\left(400 \mathrm{MHz}, \mathrm{CD}_{3} \mathrm{CN}\right): \delta$ $(\mathrm{ppm})=8.30(\mathrm{~s}, 2 \mathrm{H}), 7.39(\mathrm{~s}, 2 \mathrm{H}), 7.35(\mathrm{~s}, 2 \mathrm{H}), 3.86(\mathrm{~s}, 6 \mathrm{H}) \cdot{ }^{13} \mathrm{C}$ NMR $(100 \mathrm{MHz}$ $\left.\mathrm{CD}_{3} \mathrm{CN}\right): \delta(\mathrm{ppm})=139.69,127.74,123.89,36.54 . \mathrm{ESI}-\mathrm{MS}[\mathrm{M}]^{+}: \mathrm{m} / \mathrm{z} 361.0[\mathrm{Au}(\mathrm{N}-$ methylimidazole $\left.)_{2}\right]^{+}, \quad 395.0 \quad\left[\mathrm{Au}(\mathrm{N} \text {-methylimidazole })_{2} \mathrm{Cl}\right]^{+} \quad 431.0 \quad[\mathrm{Au}(\mathrm{N}-$ methylimidazole $\left.)_{2} \mathrm{Cl}_{2}\right]^{+}$.

Synthesis of $24 . \quad$ A solution of $5 \mathrm{IM}(66 \mathrm{mg}, 0.098 \mathrm{mmol})$ in $2 \mathrm{~mL} \mathrm{CD}_{3} \mathrm{CN}$ was added drop wise to a solution of $13(50 \mathrm{mg}, 0.098 \mathrm{mmol})$ in $2 \mathrm{~mL} \mathrm{CD}{ }_{3} \mathrm{CN}$. The mixture was stirred for 30 minutes resulting in a yellow solution. Solvent was reduced to half in vacuo followed by the addition of $5 \mathrm{~mL}$ of $\mathrm{Et}_{2} \mathrm{O}$ to afford a yellow solid. The solid was then washed with $\mathrm{Et}_{2} \mathrm{O}(3 \times 3 \mathrm{~mL})$ and dried in vacuo $\left(76 \mathrm{mg}, 70 \%\right.$ yield). ${ }^{1} \mathrm{H}$ NMR (400 $\left.\mathrm{MHz}, \mathrm{CD}_{3} \mathrm{CN}\right): \delta(\mathrm{ppm})=8.20(\mathrm{~s}, 4 \mathrm{H}), 7.32(\mathrm{~s}, 4 \mathrm{H}), 7.20(\mathrm{~s}, 4 \mathrm{H}), 3.80(\mathrm{~s}, 12 \mathrm{H}) \cdot{ }^{13} \mathrm{C}$ NMR $\left(100 \mathrm{MHz}, \mathrm{CD}_{3} \mathrm{CN}\right): \delta(\mathrm{ppm})=139.50,126.53,124.76,36.66 . \mathrm{ESI}-\mathrm{MS}[\mathrm{M}]^{+}: \mathrm{m} / \mathrm{z}$ $361.1\left[\mathrm{Au}(\mathrm{N}-\text { methylimidazole })_{2}\right]^{+}, 823.1\left[\mathrm{Au}(\mathrm{N}-\text {-methylimidazole })_{4}\right]^{3+}[\mathrm{OTf}]_{2}^{-}$. 
Synthesis of 25NMe2.

A solution of $5 \mathrm{NMe}_{2}(74 \mathrm{mg}, 0.098 \mathrm{mmol})$ in $2 \mathrm{~mL}$ $\mathrm{CD}_{3} \mathrm{CN}$ was added drop wise to a solution of 13 ( $50 \mathrm{mg}, 0.098 \mathrm{mmol}$ ) in $2 \mathrm{~mL} \mathrm{CD}_{3} \mathrm{CN}$ and stirred for 30 minutes. A color change from white to orange was observed. Solvent was reduced to half in vacuo followed by the addition of $5 \mathrm{~mL}$ of $\mathrm{Et}_{2} \mathrm{O}$ to afford a yellow solid. The solid was then washed with $\mathrm{Et}_{2} \mathrm{O}(3 \times 3 \mathrm{~mL})$ and dried in vacuo $(78 \mathrm{mg}, 76 \%$ yield). ${ }^{1} \mathrm{H}$ NMR $\left(400 \mathrm{MHz}, \mathrm{CD}_{3} \mathrm{CN}\right): \delta(\mathrm{ppm})=8.24(\mathrm{~s}, 2 \mathrm{H}), 7.95(\mathrm{~d}, 4 \mathrm{H}, J=8 \mathrm{~Hz}), 7.33$ (s, 2H), $7.22(\mathrm{~s}, 2 \mathrm{H}), 6.71(\mathrm{~d}, 4 \mathrm{H}, J=8 \mathrm{~Hz}), 3.79(\mathrm{~s}, 6 \mathrm{H}) 3.11(\mathrm{~s}, 12 \mathrm{H}) \cdot{ }^{13} \mathrm{C}$ NMR $(100$ $\left.\mathrm{MHz}, \mathrm{CD}_{3} \mathrm{CN}\right): \delta(\mathrm{ppm})=157.02,147.10,139.46,126.26,124.98,110.25,40.24,36.70$ ESI-MS [M] $]^{+}: \mathrm{m} / \mathrm{z} 361.1\left[\mathrm{Au}(\mathrm{N}-\text {-methylimidazole })_{2}\right]^{+}, 401.1[\mathrm{Au}(\mathrm{N}-$ methylimidazole $)(4-$ dmap) $]^{+}, 441.1\left[\mathrm{Au}(4-\mathrm{dmap})_{2}\right]^{+}, 902.9\left[\mathrm{Au}(\mathrm{N}-\text {-methylimidazole })_{2}(4-\mathrm{dmap})_{2}\right]^{+}[\mathrm{OTf}]_{2}{ }^{-}$.

Synthesis of $25 \mathrm{H}$. A solution of $5 \mathrm{H}(65 \mathrm{mg}, 0.098 \mathrm{mmol})$ in $2 \mathrm{~mL} \mathrm{CD} \mathrm{CDN}_{3} \mathrm{CNas}$ added drop wise to a solution of 13 ( $50 \mathrm{mg}, 0.098 \mathrm{mmol}$ ) in $2 \mathrm{~mL} \mathrm{CD}_{3} \mathrm{CN}$ and stirred for 30 minutes. A color change from white to yellow was observed. Solvent was reduced to half in vacuo followed by the addition of $5 \mathrm{~mL}$ of $\mathrm{Et}_{2} \mathrm{O}$ to afford a yellow solid. The solid was then washed with $\mathrm{Et}_{2} \mathrm{O}(3 \times 3 \mathrm{~mL})$ and dried in vacuo $\left(68 \mathrm{mg}, 72 \%\right.$ yield). ${ }^{1} \mathrm{H} \mathrm{NMR}$ $\left(400 \mathrm{MHz}, \mathrm{CD}_{3} \mathrm{CN}\right): \delta(\mathrm{ppm})=8.77(\mathrm{~d}, 4 \mathrm{H}, J=8 \mathrm{~Hz}), 8.36-8.31(\mathrm{~m}, 4 \mathrm{H}), 7.83(\mathrm{t}, 4 \mathrm{H}, J=$ $8 \mathrm{~Hz}), 7.3(\mathrm{~s}, 4 \mathrm{H}), 3.75(\mathrm{~s}, 6 \mathrm{H}) \cdot{ }^{13} \mathrm{C} \mathrm{NMR}\left(100 \mathrm{MHz}, \mathrm{CD}_{3} \mathrm{CN}\right): \delta(\mathrm{ppm})=150.75,146.29$, 139.56, $130.62, \quad 125.92, \quad 125.40, \quad 36.76 . \quad$ ESI-MS $\quad[M]^{+}: \quad m / z \quad 358.1 \quad[\mathrm{Au}(\mathrm{N}-$ methylimidazole)(pyridine $)]^{+}, \quad 361.1 \quad\left[\mathrm{Au}\left(\mathrm{N}-\text { methylimidazole }_{2}\right]^{+}, \quad 816.5 \quad[\mathrm{Au}(\mathrm{N}-\right.$ methylimidazole $\left.)_{2}(\text { pyridine })_{2}\right]^{3+}\left[\mathrm{OTff}^{2} 2\right.$. 
Synthesis of $25 \mathrm{CN}$

A solution of $5 \mathrm{CN}(278 \mathrm{mg}, 0.392 \mathrm{mmol})$ in $\mathrm{CH}_{3} \mathrm{CN}(5 \mathrm{~mL})$ was added drop wise to a solution of of $13(200 \mathrm{mg}, 0.392 \mathrm{mmol})$ in $\mathrm{CH}_{3} \mathrm{CN}(5 \mathrm{~mL})$. The mixture was then stirred for 10 minutes giving a yellow solution. The solvent was removed under reduced pressure to give a yellow solid. The solid was recrystallized from $\mathrm{CH}_{3} \mathrm{CN} / \mathrm{Et}_{2} \mathrm{O}$ (317 mg, 79\% yield). ${ }^{1} \mathrm{H}$ NMR $\left(400 \mathrm{MHz}, \mathrm{CD}_{3} \mathrm{CN}\right): \delta(p p m)=8.95(\mathrm{~d}$, $\mathrm{J}=7.0 \mathrm{~Hz}, 4 \mathrm{H}), 8.31(\mathrm{~s}, 2 \mathrm{H}), 8.18(\mathrm{~d}, \mathrm{~J}=7.0 \mathrm{~Hz} 4 \mathrm{H}), 7.33(\mathrm{~s}, 2 \mathrm{H}), 7.30(\mathrm{~s}, 2 \mathrm{H}), 3.77(\mathrm{~s}$, 6H). ${ }^{13} \mathrm{C}$ NMR $(100 \mathrm{MHz}, \mathrm{CD} 3 \mathrm{CN}): \delta(\mathrm{ppm})=152.19,139.76,133.15,129.15,125.98$, 125.52, 114.76, 36.87. ESI-MS [M] : m/z 361 [Au(N-methylimidazole $\left.)_{2}\right]^{+}$.

Synthesis of 14. $\mathrm{Au}(1,3-$ dimethylbenzimidazole $) \mathrm{Cl} \quad(300 \mathrm{mg}, \quad 0.79 \mathrm{mmol})$ was dissolved in $20 \mathrm{~mL} \mathrm{CH} \mathrm{Cl}_{2}$ followed by the addition of $640 \mu \mathrm{L}$ of pyridine $(7.9 \mathrm{mmol})$. AgOTf (203 mg, 0.79) was added to the mixture and stirred overnight in the dark. The mixture was filtered through celite and the solvent was reduced to half in vacuo. Addition of $\mathrm{Et}_{2} \mathrm{O}(20 \mathrm{~mL})$ to the mixture afforded a white solid which was washed with $\mathrm{Et}_{2} \mathrm{O}(3 \times 5 \mathrm{~mL}) .81 \%$ yield. ${ }^{1} \mathrm{H}$ NMR $\left(400 \mathrm{MHz}, \mathrm{CD}_{3} \mathrm{CN}\right): \delta(\mathrm{ppm})=8.71(\mathrm{~d}, \mathrm{~J}=4.0 \mathrm{~Hz}$ 2H), $8.18(\mathrm{br}, 1 \mathrm{H}), 7.78(\mathrm{br}, 2 \mathrm{H}), 7.69(\mathrm{dd}, J=6.2,3.1 \mathrm{~Hz}, 2 \mathrm{H}), 7.54(\mathrm{dd}, J=6.2,3.1 \mathrm{~Hz}$, $2 \mathrm{H}), 4.12(\mathrm{~s}, 6 \mathrm{H}) .{ }^{13} \mathrm{C}$ NMR $(100 \mathrm{MHz}, \mathrm{CD} 3 \mathrm{CN}): \delta(\mathrm{ppm})=173.11,152.54,142.64$, 134.86, 127.80, 125.74, 112.84, 36.10. ESI-MS $[\mathrm{M}]^{+}: \mathrm{m} / \mathrm{z} \quad 384.0 \quad[\mathrm{Au}(1,3-$ dimethylbenzimidazolole) $\left.\left(\mathrm{CH}_{3} \mathrm{CN}\right)\right]^{+}, 422.0[\mathrm{Au}(1,3-\text { dimethylbenzimidazole)(pyridine })]^{+}$.

Synthesis of $26 . \quad$ A solution of $5 \mathrm{H}(59 \mathrm{mg}, 0.088 \mathrm{mmol})$ in $\mathrm{CH}_{3} \mathrm{CN}(2 \mathrm{~mL})$ was added drop wise to a solution of 14 (50 $\mathrm{mg}, 0.088 \mathrm{mmol})$ in $\mathrm{CH}_{3} \mathrm{CN}(2 \mathrm{~mL})$. The mixture was then stirred for 30 minutes giving a yellow solution. The solvent was removed under 
reduced pressure to give a yellow solid which was recrystallized from $\mathrm{CH}_{3} \mathrm{CN} / \mathrm{Et}_{2} \mathrm{O}$. (62 mg, $68 \%$ yield). ${ }^{1} \mathrm{H}$ NMR $\left(400 \mathrm{MHz}, \mathrm{CD}_{3} \mathrm{CN}\right): \delta(\mathrm{ppm})=8.81(\mathrm{~d}, \mathrm{~J}=7.96 \mathrm{~Hz}, 4 \mathrm{H}), 8.44-$ $8.40(\mathrm{~m}, 4 \mathrm{H}), 8.33(\mathrm{t}, \mathrm{J}=7.72 \mathrm{~Hz}, 1 \mathrm{H}), 7.88(\mathrm{t}, J=7.72,4 \mathrm{H}), 7.78(\mathrm{dd}, J=6.44,3.16$ $\mathrm{Hz}, 2 \mathrm{H}), 7.76-7.72(\mathrm{~m}, 2 \mathrm{H}), 7.63(\mathrm{dd}, J=6.32,3.24 \mathrm{~Hz}, 2 \mathrm{H}), 4.18(\mathrm{~s}, 6 \mathrm{H}) .{ }^{13} \mathrm{C}$ NMR $(100$ $\mathrm{MHz}, \mathrm{CD} 3 \mathrm{CN}): \delta(\mathrm{ppm})=152.31,150.87,147.10,145.79,135.26,131.59,129.55$ 128.16, 114.20, 36.11. ESI-MS $[\mathrm{M}]^{+}: \quad \mathrm{m} / \mathrm{z} \quad 719.1 \quad[\mathrm{Au}(1,3-$ dimethylbenzimidazole)(pyridine $)]^{3+}\left[\mathrm{OTff}^{2} 2\right.$, 798.4 $[\mathrm{Au}(1,3-$ dimethylbenzimidazole)(pyridine $\left.)_{2}\right]^{3+}\left[\mathrm{OTf}_{2}{ }_{2}\right.$, 877.8 $[\mathrm{Au}(1,3-$ dimethylbenzimidazole)(pyridine) $\left.]_{3}\right]^{3+}\left[\mathrm{OTf}^{-}{ }^{-}\right.$.

\section{References}

1. Schmidbaur, H.; Schier, A., Gold(III) Compounds for Homogeneous Catalysis: Preparation, Reaction Conditions, and Scope of Application. Arab. Sci. Eng. 2012, 37, 1187-1225.

2. Labinger, J. A.; Bercaw, J. E., Understanding and exploiting $\mathrm{C}-\mathrm{H}$ bond activation. Nature 2002, 417, 507.

3. Brand, J. P.; Waser, J., Direct Alkynylation of Thiophenes: Cooperative Activation of TIPS-EBX with Gold and Brønsted Acids. Angew. Chem., Int. Ed. 2010, 49, 7304-7307.

4. Brand, J. P.; Charpentier, J.; Waser, J., Direct Alkynylation of Indole and Pyrrole Heterocycles. Angew. Chem., Int. Ed. 2009, 48, 9346-9349.

5. Ball, L. T.; Lloyd-Jones, G. C.; Russell, C. A., Gold-Catalyzed Direct Arylation. Science 2012, 337, 1644.

6. Ball, L. T.; Lloyd-Jones, G. C.; Russell, C. A., Gold-Catalyzed Oxidative Coupling of Arylsilanes and Arenes: Origin of Selectivity and Improved Precatalyst. J. Am. Chem. Soc. 2014, 136, 254-264.

7. Hofer, M.; Nevado, C., Cross-coupling of arene-gold(III) complexes. Tetrahedron 2013, 69, 5751-5757.

8. Qiu, D.; Zheng, Z.; Mo, F.; Xiao, Q.; Tian, Y.; Zhang, Y.; Wang, J., Gold(III)-Catalyzed Direct Acetoxylation of Arenes with lodobenzene Diacetate. Org. Lett. 2011, 13, 4988-4991.

9. Li, Z.; Ding, X.; He, C., Nitrene Transfer Reactions Catalyzed by Gold Complexes. J. Org. Chem. 2006, 71, 5876-5880. 
10. Orbisaglia, S.; Jacques, B.; Braunstein, P.; Hueber, D.; Pale, P.; Blanc, A.; de Frémont, P., Synthesis, Characterization, and Catalytic Activity of Cationic NHC Gold(III) Pyridine Complexes. Organometallics 2013, 32, 4153-4164.

11. Corbo, R.; Pell, T. P.; Stringer, B. D.; Hogan, C. F.; Wilson, D. J. D.; Barnard, P. J.; Dutton, J. L., Facile Formation of Homoleptic Au(III) Trications via Simultaneous Oxidation and Ligand Delivery from [PhI(pyridine)2]2+. J. Am. Chem. Soc. 2014, 136, 12415-12421.

12. Pell, T. P.; Couchman, S. A.; Ibrahim, S.; Wilson, D. J. D.; Smith, B. J.; Barnard, P. J.; Dutton, J. L., Diverse Reactions of Phl(OTf)2 with Common 2-Electron Ligands: Complex Formation, Oxidation, and Oxidative Coupling. Inorg. Chem. 2012, 51, 13034-13040.

13. Weigand, J. J.; Burford, N.; Decken, A.; Schulz, A., Preparation and Characterization of a Ligand-Stabilized Trimethylphosphane Dication. Eur. J. Inorg. Chem. 2007, 2007, 48684872.

14. Albayer, M.; Dutton, J. L., Reactions of Trivalent lodine Reagents with Classic Iridium and Rhodium Complexes. Aust. J. Chem. 2017, 70, 1180-1187.

15. Krawczyk, E.; Skowrońska, A.; Michalski, J., Studies on the interaction of phosphine selenides and their structural analogues wth dihalogens and sulfuryl chloride. J. Chem. Soc., Dalton Trans. 2002, 4471-4478.

16. Mézailles, N.; Ricard, L.; Gagosz, F., Phosphine Gold(I) Bis(trifluoromethanesulfonyl)imidate Complexes as New Highly Efficient and Air-Stable Catalysts for the Cycloisomerization of Enynes. Org. Lett. 2005, 7, 4133-4136.

17. Abbehausen, C.; Peterson, E. J.; de Paiva, R. E. F.; Corbi, P. P.; Formiga, A. L. B.; Qu, Y.; Farrell, N. P., Gold(I)-Phosphine-N-Heterocycles: Biological Activity and Specific (Ligand) Interactions on the C-Terminal HIVNCp7 Zinc Finger. Inorg. Chem. 2013, 52, 1128011287.

18. Fairfull-Smith, K. E.; Jenkins, I. D.; Loughlin, W. A., Novel polymer-supported coupling/dehydrating reagents for use in organic synthesis. Org. Biomol. Chem. 2004, 2, 1979-1986.

19. Moussa, Z.; Ahmed, S. A.; ElDouhaibi, A. S.; Al-Raqa, S. Y., NMR Studies and electrophilic properties of triphenylphosphine-trifluoromethanesulfonic anhydride; a remarkable dehydrating reagent system for the conversion of aldoximes into nitriles. Tetrahedron Letters 2010, 51, 1826-1831.

20. Lin, J. C. Y.; Tang, S. S.; Vasam, C. S.; You, W. C.; Ho, T. W.; Huang, C. H.; Sun, B. J.; Huang, C. Y.; Lee, C. S.; Hwang, W. S.; Chang, A. H. H.; Lin, I. J. B., Structural, Photophysical, and Catalytic Properties of $\mathrm{Au}(\mathrm{I})$ Complexes with 4-Substituted Pyridines. Inorg. Chem. 2008, 47, 2543-2551.

21. Hsu, S. J.; Hsu, K. M.; Leong, M. K.; Lin, I. J. B., Au(i)-benzimidazole/imidazole complexes. Liquid crystals and nanomaterials. Dalton Trans. 2008, 1924-1931.

22. Oh, M.-S.; Jung, S.-H.; Choi, S.-H., Preparation of radioisotope nanoparticles constructed with Au-ligand framework by self-assembly process for radiotracer. J. Radioanal. Nucl. Chem. 2014, 302, 1151-1158.

23. Albayer, M.; Corbo, R.; Dutton, J. L., Well defined difluorogold(iii) complexes supported by N-ligands. Chem. Commun. 2018, 54, 6832-6834.

24. Price, G. A.; Brisdon, A. K.; Flower, K. R.; Pritchard, R. G.; Quayle, P., Solvent effects in gold-catalysed A3-coupling reactions. Tetrahedron Letters 2014, 55, 151-154. 
25. Zhao, X.-F.; Zhang, C., lodobenzene Dichloride as a Stoichiometric Oxidant for the Conversion of Alcohols into Carbonyl Compounds; Two Facile Methods for Its Preparation. Synthesis 2007, 2007, 551-557.

26. Weiss, R.; Seubert, J., Electrostatic Activation of Hypervalent Organo-lodine Compounds:

Bis(onio)-Substituted Aryliodine(III) Salts. J. Angew. Chem., Int. Ed. 1994, 33, 891-893. 